\title{
Medya Kullanımı ve Beden İmajı: Türkiye ve İngiltere Örneği
}

\author{
Elif Eșiyok Sönmez ${ }^{1}$ \\ Özlen Özgen²
}

\begin{abstract}
Öz
Bu çalışmanın amacı, Türkiye ve İngiltere'de yaşayan üniversite öğrencilerinin beden imajlarına ilişkin düşüncelerinde medyanın rolünün ortaya konulmasıdır. Araştırma kapsamına Türkiye'den 381, İngiltere'den 235 üniversite öğrencisi alınmıştır. Verilerin toplanmasında, demografik bilgiler ve medya kullanım alışkanlıkları ile ilgili soruların yanı sıra "Dış Görünüşe İlişkin Sosyo-Kültürel Tutumlar Ölçeği”nin yer aldığı bir anket formu kullanılmıştır. Geçerlik ve güvenirlik analizi yapılmış, elde edilen sonuçlar her iki ülke için de ölçeğin geçerlik ve güvenirliğini ortaya koymuştur. İki ülke için yapılan faktör analizi sonucunda da beden imajı ve medyaya ilişkin geçerli bir faktörleşme elde edilmiştir. Geleneksel medyadan ve sosyal medyadan kaynaklanan baskı hissedilmesi, medyadaki ünlülerle bedenin karşılaştırılması, medyadaki ünlülere benzemeye çalışıması ve ideal beden farkındalığı faktörlerine uygulanan t-testi sonuçları, Türkiye ve İngiltere arasında anlamlı farklar bulunduğunu, tüm faktörler için İngiltere'deki ortalama değerlerin Türkiye'deki değerlerden yüksek olduğunu göstermiştir. Ayrıca, Türkiye ve İngiltere için önerilen modelin testi için LISREL programı ile Path Analizi yapılmıştır. Türkiye için, bilgi kaynağı olarak geleneksel medya, geleneksel medyadan ve sosyal medyadan kaynaklanan baskı hissedilmesi ve ideal beden farkındalığının, medyadaki ünlülerle bedenin karşılaştırılması ve ünlülere benzemeye çalışılması değişkenlerini açıkladığı bulunmuştur. Ingiltere için ise, geleneksel medyadan kaynaklanan baskı hissedilmesi ve ideal beden farkındalığının, medyadaki ünlülerle bedenin karşılaştırılması değişkenini açıkladığı; medyadaki ünlülerle bedenin karşılaştırımasının ise, medyadaki ünlülere benzemeye çalışılması değişkenini açıkladığı görülmüştür. Bu sonuç, özellikle geleneksel medyanın her iki ülkede de üniversite öğrencilerinin beden imajlarına ilişkin düşüncelerinde önemli bir rol üstlendiğini göstermiştir.
\end{abstract}

Anahtar Kelimeler: Beden, İdeal Beden, Beden İmajı, Medya

\section{Media Usage And Body Image: An Example Of Turkey And The Uk}

\begin{abstract}
The purpose of this study is to examine the role of media on ideas of university students from different countries regarding body image. 381 undergraduate students from Turkey and 235 undergraduate students from the UK participated in this study. In order to achieve the purpose of the research, a questionnaire that consists of questions on "demographic information", "media habits" and "Socio-cultural Attitudes Towards Appearance Scale" was designed. The reliability and validity analyses of the study
\end{abstract}

1 Yrd. Doç. Dr., Atılım Üniversitesi, İşletme Fakültesi, Halkla İlişkiler ve Reklamcılık Bölümü 2 Prof. Dr., Gazi Üniversitesi, İletişim Fakültesi, Halkla Illişkiler ve Tanıtım Bölümü 
were conducted and the results revealed that the scale was reliable and valid for both countries. A valid factorization related to body image and media was obtained from the factor analyses. Results from t-tests between Turkey and the UK indicated significant differences in the factors pressure of the media, comparing the body with the people in the media, trying to look like the people in the media, and awareness of the ideal body. Average scores for all of the factors were found to be higher in the UK than those of in Turkey. Two separate Path Models were estimated for Turkey and the UK through LISREL program. For Turkey, the results showed that the factors, traditional media as a source of information, pressure of the traditional media, pressure of the social media, and the awareness of the ideal body were observed to cause people to compare themselves with the people in the media and consequently to try to look like them. For the UK, pressure of the traditional media, and the awareness of ideal body were observed to cause people to compare themselves with the people in the media and consequently to try to look like them. As a result, in both countries, it was found out that traditional media, in particular, had a role on ideas related with body image of the university students.

Keywords: Body, Ideal Body, Body Image, Media 


\section{Giriș}

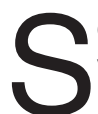
osyoloji, antropoloji, psikoloji ve iletişim gibi disiplinler bedenin anlamı, var oluşu ve önemi ile ilgili sorulara cevap aramaktadır. Bedenin medyada yer alan yazılar, kullanılan görseller, yayınlanan programlar veya sosyal ağlar üzerinden yapılan paylaşımlar ile yeniden biçimlenerek çeşitli ideallerle kuşatılması, medyanın beden üzerindeki etkilerini güncel konulardan biri haline getirmiştir.

Özellikle reklamlar, popüler gazeteler, televizyon programları ve filmler önceden biçimlendirilmiş ve idealize edilmiş beden imgelerin yayılmasına olanak sağlamaktadır (Featherstone, 1993: 170). Medya sadece ideal bedeni değil, aynı zamanda bu ideallere ulaşmak için neler yapılması gerektiğini ve yöntemlerini de yayan bir araçtır. Dolayısı ile, kendisini medyada yer alan ideal beden ile karşılaştıran birey, bu karşılaştırma sonucunda o ideal bedene ulaşmak için göstereceği çabaları da yine medyadan öğrenmektedir (Warren and Rios, 2013).

Medya ve beden arasındaki tartışmalardan hareketle, bu çalışmanın amacı iki farklı ülkede yaşayan üniversite öğrencilerinin beden imajına ilişkin düşüncelerinde medyanın rolünü ortaya koymaktır. Çalışmada bilgi kaynağı olarak medya, medyadan kaynaklanan baskı hissedilmesi ve ideal beden farkındalığı faktörleri ile medyadaki ünlülerle bedenin karşılaştırılması ve ünlülere benzemeye çalışılması faktörleri arasındaki ilişkinin ortaya konulacağı bir model geliştirilmiştir. Medya kullanımı kapsamında geleneksel medya araçlarını temsilen dergi, gazete, televizyon; yeni medya araçlarını temsilen sosyal ağlar, video ağları, mikroblog, fotoğraf ağları ve bloglar seçilmiştir.

Araştırma kapsamında, beden imajına ilişkin yaklaşımlarda hem geleneksel, hem sosyal medyanın rollerinin karşılaştırmalı olarak ele alınmasının literatüre yenilik katacağı düşünülmektedir. Önceki araştırmaların çoğunda gazete ve sosyal medya araştırmalara dahil edilmemiş, sadece dergi ve televizyon kullanımı ve beden imajı ile ilişkili çalışmalar yapılmıştır. Bunun yanı sıra Türkiye ve İngiltere'deki üniversite öğrencilerinin beden imajlarına ilişkin düşüncelerinde medyanın rolü ilk defa karşılaştırmalı olarak incelenmektedir.

\section{1. İdeal Beden ve Beden İmajı}

Bedene ilişkin bir analiz yapabilmek için, onun materyal, fiziksel ve biyolojik bir olgu olmanın ötesinde güncel ve sosyal süreçlerin ayrılmaz bir parçası olduğunun da kabul edilmesi gerekir (Schilling, 1993: 8). Gün içinde bireyler dış görünüşlerine ilişkin birden fazla uyarana maruz kalmaktadırlar. Bu uyaranlar dergiler, mağaza vitrinleri, kişiler arasında geçen günlük diyaloglar ve/ya estetik cerrahi operasyonlarının artışı gibi çeşitli etmenler ile bireylere ulaşmakta ve dış görünüşlerine ilişkin baskı yaratmaktadır (Tiggemann, 2011). Bu baskının sonucunda, kişinin kendi bedenini nasıl gördüğü konusu ön plana çıkmaktadır. Kişinin kendi bedenine ilişkin düşünceleri söz konusu olduğunda ise, bireyin beden imajı önem kazanmaktadır.

Beden imajı kavramı, Avustralyalı psikiyatrist Paul Ferdinand Schilder tarafından geliştirilmiştir. Schilder beden imajını, bireyin kendi bedenine karşı oluşan "mental imaj” olarak açıklamaktadır (1950: 19). Bu mental imaj, objektif bir değerlendirme değil, 
zihinsel bir oluşumdur (Bell'den akt. Myers ve Biocca, 1992) ve aynı zamanda kişinin aynaya baktığında zihinsel olarak kendisini nasıl gördüğü ve zihinsel olarak bedenin şeklini nasıl algıladığı ile ilişkilidir.

Beden imajı değişime açıktır ve özellikle yaşamının ilk on yılında sürekli inşa halindedir (Beyazyüz ve Göka, 2011: 375). Ancak, bu inşa süreci yaşamın ilk on yılından sonra da bitmemektedir. Çünkü bireyin kendi vücuduna karşı olan yargıları onu çevreleyen dünya ile olan etkileşimi sayesinde oluşmakta ve bu da bireyin tüm yaşam sürecini kapsamaktadır (Oğuz, 2005: 32). Dolayısı ile beden imajı oluşumunu belirli yıllar ve zaman aralıkları ile ifade etmek oldukça zordur. Beden sürekli yeniden inşa edilmektedir.

Beden imajını oluşturan çeşitli bileşenler bulunmaktadır. Bu bileşenler; algılar (bir kişinin beden ebat ve ölçülerini kendi zihninde nasıl canlandırdığı), tutumlar (hem bilişsel hem de duygusal olarak kendi bedeni hakkındaki düşüncelerinin incelik idealine ne şekilde uyduğu) ve davranışlar (ölçülü yemek yeme, aşırı yemek yeme, aşırı spor ve diyet yapmak) olarak sıralanmaktadır (Botta,1999). Başka bir yaklaşıma göre zihinsel, davranışsal ve duygusal katmanlar içeren beden imajı, birtakım içsel ve dışsal faktörler ile şekillenmektedir. Biyolojik ve psikolojik faktörler içsel, kültürel ve sosyal olgular ise dışsal faktörleri oluşturmaktadır (Goswami, vd. 2012). Kültürel ve sosyal olgular söz konusu olduğunda ise akla gelen bir diğer araç medya ve onun beden imajı üzerindeki etkilerdir.

Medyanın beden imajı üzerindeki etkisi literatürde çoğunlukla sosyo-kültürel yaklaşım ile bağlantılı olarak ele alınmıştır. Sosyo-kültürel yaklaşım aile, arkadaşlar ve medyadan oluşan üçlü bir modele işaret etmektedir ve bu nedenle "Üçlü Model" (Tripartite) olarak da anılmaktadır. Sosyo-kültürel yaklaşıma göre, toplumların ideal beden anlayışları vardır. Bu ideal bedene ilişkin özellikler medyada belirli anahtar kelime ve kavramlar aracılığı ile betimlenir. Örneğin zayıf olmak, kaslı olmak ve fiziksel zindelik genç olmak ile eşdeğer tutularak, yaşlanan beden, kişi için kaygı kaynağı haline getirilmektedir (Özbolat, 2011). Şişman olmak, bakımsız görünmek veya yaşlanmak kaçınılması gereken durumlar olarak sunulmaktadır. Bu sunulan ve yayılan ideal beden şekilleri kültürden kültüre farklılık gösterebilir. Belirli bir kültüre ait güzellik ve ideal beden anlayışı, çeşitli sosyo-kültürel kanallar ile yayılarak, bireyler tarafından içselleştirilir ve kendi bedenlerine ilişkin tatmin ya da tatminsizliklere neden olur (Tiggeman, 2011).

Sosyo-kültürel faktörler kişilerde kendi bedenlerine ilişkin farkındalık, beden ideallerinin içselleştirilmesi ve ideal bedene sahip olmak için hissedilen baskıdan oluşan üç sonuca neden olur. Farkına varma süreci "incelik idealini pasif olarak desteklemek", içselleştirme "incelik idealini aktif olarak desteklemek" ve hissedilen baskılar ise "ince olmak için hissedilen baskılar" olarak sınıflandırılmaktadır (Cafri vd., 2005). Farkındalık, içselleştirme ve bedene ilişkin olarak medyadan kaynaklanan baskılar çeşitli araştırmalara konu olmuştur.

Farklı cinsiyetteki bireylerin beden imajı üzerine yapılan birçok çalışmada, sosyo-kültürel faktörleri oluşturan aile, arkadaş ve medyanın kişilerin bedenlerini değiştirmelerine yönelik kararlarında etkili olduğu ortaya konulmuştur (Irving, 1990; Hill ve Franklin, 1998; Ricciardeli, vd. 2000; Jones, 2011). Medya özelinde bakıldığında ise, dergi, televizyon, gazete, film, reklam ve müzik videolarının bireylerin beden imajına ilişkin algılarını etkilemenin yanı sıra, ideal bedene ilişkin özellikleri de yaydığı 
düşünülmektedir (Silverstein, vd., 1986). Bu noktadan hareketle, medya araçlarının hem bedenin nasıl olması gerektiğine ilişkin imgeler gönderen bir bilgi kaynağı olduğu, hem de bu "ideal" bedene ulaşmak için çeşitli öneri ve çözümler sunan bir araç olduğu söylenebilir.

\section{Medya ve Beden İmajı}

Beden imajına ilişkin ideallerin yayılmasında kullanılan araçlar arasında en çok tartışılan dergilerdir. Özellikle bedene ilişkin düşüncelerde genç kızlar açısından dergileri takip etmenin televizyon izlemekten daha etkili olduğu ve güzellik idealinin içselleştirilmesinde doğrudan etkisinin olduğu ortaya konulmuştur (Tiggeman ve McGill, 2004; Levine ve Chapman, 2011). Bu etkinin doğrudan olmasındaki en büyük sebeplerden birisi, okuyucuların ilgi alanları doğrultusunda dergi içeriklerini okumalarıdır. Belirli ilgi alanları doğrultusunda satın alınıp okunan dergiler, bu özellikleri ile diğer medya araçlarından ayrılmaktadır. Amerika Birleşik Devletleri'nde yaşları 1119 arasında değişen 500 kız öğrenci üzerinde yapılan bir araştırmada katılımcıların \%69'unun zihinlerinde dergilerde yer alan kişiler ile bağlantılı olarak ideal beden şeklinin oluştuğu, \%47'sinde ise bu görselleri gördükten sonra kilo verme arzusunun meydana geldiği gözlemlenmiştir (Field, vd. 2001). Ayrıca, genç kızların bedenlerini, moda/güzellik dergilerinde yer alan kişilerin bedenleri ile karşılaştırmaları sonucunda kendi bedenlerinden memnuniyetsizlik duydukları da bilinmektedir. (Levine ve Chapman, 2011). Yaşları 18-42 arasında değişen, 150 kadın ve erkeğin dahil edildiği bir başka çalışmada, güzellik dergisi okumanın kadınların ideal beden farkındalığının artmasında ve beden memnuniyetsizliğinin ortaya çıkmasında etkili olduğu; erkeklerde ise spor dergilerinin ideal beden farkındalığını arttırdığı ve bedenlerine ilişkin memnuniyetsizlik yarattığı sonucuna ulaşılmıştır (Morry ve Staska, 2001). Yapılan araştırmaların sonuçlarından hareketle; özellikle ideal bedenin yaratılmasında ve kişilerin kendi bedenlerini sorgulamalarında, dergilerin etkisinin önemli olduğunu söylemek mümkündür.

Beden imajı ve medya ile ilgili çalışmalarda televizyonun etkisi de araştırılmıştır. Bunun bir nedeni de televizyonda yer alan şovların, haberlerin ve eğlence programlarının sadece izleyiciyi eğlendirmek ya da bilgilendirmekle yetinmediği, aynı zamanda beden imajına ilişkin idealleri de yaydığının düşünülmesidir (Graydon, 2008). Medyada yer alan kişiler bu idealleri yayacak beden şekline sahip kişiler arasından bilinçli olarak seçilmektedir.

Televizyon izlemenin beden imajı üzerindeki etkilerini araştıran çalışmalarda, televizyonda sunulan imajların bireylerin beden imajlarını sorgulamalarına neden olduğu sonucuna varılmıştır (Richins, 1991; Myers ve Biocca, 1992; Tiggeman ve Pickering, 1996; Harrison ve Cantor, 1997; Botta, 1999). Özellikle, diziler ve müzik videolarının izlenmesi ile incelik idealinin oluşması arasında anlamlı bir ilişki bulunmuştur (Tiggemann ve Pickering, 1996; Tiggemann, 2006). Dizi ve filmlerdeki oyuncular, müzik videolarında yer alan dansçılar ve sanatçılar, güzellik yarışmalarında yarışan adaylar ve diğer pek çok televizyon programı gerek görsel gerek sözel olarak ideal bedenin oluşmasında ve yayılmasında önemli aracılardır.

Bireyin beden imajını etkileyen bir diğer araç ise gazetelerdir. Gazete ve beden imajı arasındaki ilişkinin incelendiği çok fazla çalışmaya rastlanmamıştır. Ancak 
gazetelerde sıklıkla haberlerin içinde ideal bedenden bahsedildiği görülmektedir. Özellikle ünlü kişiler aracılığı ile 'haber' adı altında zayıflığın ve genç görünmenin önemine vurgu yapılmaktadır. İtalya'da 1985-1995 yılları arasında yayınlanan ulusal gazete ve dergilerdeki 347 yayının incelendiği bir çalışma güzellik idealinin özellikle spor, güzellik, vücut bakımı ve kozmetik cerrahi haberlerinin içinde verildiğini ortaya koymuştur (Mondini, vd., 1996).

Sosyal medya ise beden imajını etkileyen bir diğer medya aracıdır. Son yıllarda yeni çevrimiçi platformların ortaya çıkması ve bu platformların insanlara birbirleri ile etkileşime girme olanağı sağlaması (Hollenbeck ve Kaikati, 2012: 395) sosyal medyanın önemini artırmıştır. Medya, aile ve yakın arkadaş gruplarının beden imajı üzerindeki etkileri çalışılmış olsa da, sosyal medyanın beden imajı üzerindeki etkisini araştıran çok fazla çalışmaya rastlanmamıştır. Ancak, sınırlı sayıdaki araştırmalardan biri olan ve Almanya'da yapılan bir çalışmada sosyal medyayı kullanan kişilerin arkadaşlık ilişkilerinin kalitesi, internette geçirdikleri süre ve güzellik ile ilgili ideallerin içselleştirilmesi arasında anlamlı bir ilişki bulunmuştur (Selfhout, vd. 2009). Bir diğer çalışmada ise, Facebook arkadaş sayısı ile kişinin kendisini iyi hissetmesi arasında anlamlı bir ilişki olduğu; hatta kişinin profilinde yer alan fotoğraflara Facebook arkadaşlarının yaptıkları yorumların bireyin öz-güvenini arttırdığı görülmüştür (Lee vd., 2014).

\section{Metod}

\section{1. Örneklem Yöntemi ve Örneklem Seçimi}

Araştırma evrenini Türkiye ve İngiltere'deki üniversite öğrencileri oluşturmaktadır. Araştırma bölgesi Türkiye'de Ankara, İngiltere'de ise Leeds şehridir. Araştırma kapsamına Türkiye'den Gazi Üniversitesi ve İngiltere'den Leeds Beckett Üniversitesi alınmıştır. Gazi Üniversitesi İletişim Fakültesi’nden 1550 öğrenci arasından \%95 güven düzeyi ile 381 öğrenci, Leeds Beckett Üniversitesi'nden ise "Pazarlama, Halkla îlişkiler ve İletişim Fakültesi”nden toplam 460 öğrenci arasından \%95 güven düzeyi ile 235 öğrenci araştırmaya dahil edilmiştir. Alan araştırmasına katılacak öğrencilerin belirlenmesinde, sistematik rastlantısal örnekleme yöntemi kullanılmıştır.

\subsection{Veri Toplama Yöntem ve Araçları}

Araştırma verilerinin toplanmasında, demografik bilgiler ve medya kullanım alışkanlıkları ${ }^{3}$ ile ilgili soruların yanı sıra "Dış Görünüşe İlişkin Sosyo-Kültürel Tutumlar Ölçeği”ne yer verilen bir anket formu kullanılmıştır.

Türkiye'den 381, İngiltere'den 235 katılımcıya uygulanan anket formları değerlendirilerek, yapı geçerliği ve güvenirlik analizi yapılmıştır. Anket formunda yer alan; bilgi kaynağı olarak medya, medyadan kaynaklanan baskı hissedilmesi, medyada yer alan ünlülere benzemeye çalışılması, medyadaki ünlülerle bedenin karşıllaştırılması ve ideal beden farkındalığı alt ölçeklerinin yapı geçerliğini kontrol etmek için, faktör analizi tekniklerinden biri olan "Döndürülmüş Temel Bileşenler Analizi" uygulanarak, anket formunda aynı ve farklı yapıları ölçen cümleler belirlenmiş ve cümlelerin bir yapı altında yer alıp almadığı madde faktör yük değerleri ile incelenmiştir.

3 Sosyal medya için ağ türleri belirlenirken DelValle Institude Knowledge Base sınıflandırması dikkate alınmıştır. Buna göre Sosyal Ağlar: Facebook, Google+ ve Linkedin; Video: Youtube, Vimeo ve Vine; Mikroblog: Twitter ve Tumblr; Fotoğraf: Instagram, Flickr ve Pinterest; Blog: Wordpress ve Blogger 
Çalışmada, Heinberg ve Thompson'un 1995 yılında geliştirdiği SATAQ ölçeğinin, 2004 yılında Thompson tarafından revize edilerek yenilenmiş ve güncellenen son hali kullanılmıştır (Thompson, vd., 2004). Beşli Likert ölçeği kullanılarak hazırlanan SATAQ3-R ölçeğinde "kesinlikle katılmıyorum", "katılmıyorum", "kararsızım", "katılıyorum" ve "kesinlikle katılıyorum" seçeneklerini içeren toplam 38 cümle bulunmaktadır Bu cümlelerin dokuzu medyanın dış görünüşe ilişkin değerlendirmelerde bilgi kaynağı olarak görülmesi, yedisi medyadan kaynaklanan baskı hissedilmesi, altısı televizyon ve dergiler aracılığı ile dış görünüșe ilişkin baskı hissedilmesi, üçü sporcuların dış görünüşlerinin içselleștirilmesi, dördü ünlüler ile kişinin kendi bedenini karşılaştırması ve dokuzu da medyanın ideal beden farkındalığını yaratma üzerindeki önemini ölçmek üzere hazırlanmıştır. Ölçeğin Cronbach's Alpha değeri .96'dır.

SATAQ-3R ölçeğinde sadece dergi ve televizyon ile ilgili cümleler yer almaktayken, bu araştırmada, ölçeğe dergi ve televizyona ek olarak sosyal medya ve gazeteyi de içeren cümleler eklenmiştir. Ayrıca, orijinal ölçekte "televizyon ve dergilerdeki kişiler ile kendimi karşılaştırırım" gibi cümleler yeterli bulunmuşken, bu araştırmada her medya aracı için sorular ayrı cümleler ile belirtilmiştir. Araştırmanın amacı doğrultusunda bir uyarlama çalışması yapılarak, ölçeğe 14 cümle eklenmiş ve toplam 52 cümleye ulaşılmıştır. Ölçeğin son halinde yer alan 14 cümle bedene ilişkin düşüncelerde "bilgi kaynağı olarak medya", 20 cümle "medyadan kaynaklanan baskı hissedilmesi", dört cümle "medyada yer alan ünlülerle bedenini karşılaştırma", beş cümle "medyada yer alan ünlülere benzemeye çalışma" ve dokuz cümle "ideal beden farkındalığını" ölçmektedir. Medyada yer alan ünlülerin meslek gruplarının araştırma kapsamına alınmamış olmasından dolayı, ölçekte bulunan sporculara ilişkin dış görünüşten etkilenme cümleleri hazırlanan anket formuna dahil edilmemiştir. Ölçeklerin güvenirlik ve geçerliği her iki ülke için ayrı ayrı yapılmıştır.

Türkiye örneği için yapılan analiz sonucunda, madde toplam korelasyon değerlerinin .212 ile .741 arasında değiştiği görülmüştür. Ölçeğin güvenirliği için hesaplanan Cronbach's Alpha değeri .964 ile geçerli bulunmuştur. Açıklanan toplam varyans $\% 75,90$ çıkmış ve literatürde geçerli kabul edilebilir sınır olan \%66,0'dan yüksek bulunmuştur. Faktör yük değerlerinin .529 ile .858 arasında değiştiği, Kaiser-MeyerOlkin ölçümünün ise .928 olduğu görülmüştür. Hesaplamalar korelasyon katsayı açısından da anlamlıdır $(\mathrm{p}<.05)$.

Türkiye'de toplanan verilere bağlı olarak yapılan faktör analizi sonucunda; 11 cümle "Bilgi kaynağı olarak geleneksel medya", üç cümle "Bilgi kaynağı olarak sosyal medya", 15 cümle "Geleneksel medyadan kaynaklanan baskı hissedilmesi", beş cümle "Sosyal medyadan kaynaklanan baskı hissedilmesi", dört cümle "Medyada yer alan ünlülerle bedenin karşılaştırılması", beş cümle "Medyada yer alan ünlülere benzemeye çalışılması" ve dokuz cümle "Ideal beden farkındalığı" başlıkları altında faktörleşmiştir.

Ingiltere için yapılan analiz sonucunda ise, madde toplam korelasyon değerinin .330 ile .723 arasında değiştiği görülmüştür. Ölçeğin güvenirliği için hesaplanan Cronbach's Alpha değeri .960, açıklanan toplam varyans \%72,68 olarak bulunmuştur. Faktör yük değerlerinin .557 ile .879 arasında değiştiği görülmüştür. Kaiser-Meyer-Olkin ölçümü ise .910 olarak bulunmuştur. Hesaplamalar korelasyon katsayısı açısından anlamlı bulunmuştur $(p<, 05)$. Ölçeğin güvenirliğine ilişkin hesaplanan Cronbach's Alpha ve açıklanan varyans değerleri "Dış Görünüşe İlişkin Sosyo-Kültürel Tutumlar" ölçeğinin geçerlik ve güvenirliği kanıtlanmış bir araç olduğunu göstermektedir. 
İngiltere'de toplanan veriler üzerinden yapılan faktör analizi sonucunda; 11 cümle "Bilgi kaynağı olarak gazete haricindeki medya", üç cümle "Bilgi kaynağı olarak gazete", beş cümle "Dergiden kaynaklanan baskı hissedilmesi", beş cümle "Gazeteden kaynaklanan baskı hissedilmesi", beş cümle "Televizyondan kaynaklanan baskı hissedilmesi", beş cümle "Sosyal medyadan kaynaklanan baskı hissedilmesi", dört cümle "Medyada yer alan ünlülerle bedenin karşılaştırılması", beș cümle "Medyada yer alan ünlülere benzemeye çalışılması" ve dokuz cümle "İdeal beden farkındalığı" olarak faktörleşmiştir.

Model testleri, yapısal eşitlik modeli türü olan "Path Analizi” ile test edilmiştir. En iyi uyum indeksi sonuçları elde edilinceye kadar LISREL programında analiz tekrarlanmıştır.

\subsection{Araștırmanın Sınırlılıkları}

Her çalışmanın olduğu gibi bu çalışmanın da bazı sınırıılıkları bulunmaktadır. Bu çalışmanın temel sınırlıığı, araştırmanın Türkiye ve İngiltere'deki birer üniversitenin birer fakültesinde yapılmış olmasıdır. Bu nedenle çalışma tüm nüfusa genellemez. Farklı gelir, yaş grubu ve mesleklere sahip kişilerin dahil edildiği araştırmalardan daha geniş kapsamlı sonuçlar elde edilebilir.

\section{Bulgular ve Değerlendirme}

Türkiye'deki katılımcıların \%53,0'ünü kadınlar, \%47,0'sini erkekler oluştururken; İngiltere'deki katılımcıların \%55,4'ünü kadınlar, \%44,6'sını erkekler oluşturmaktadır. Türkiye'deki katılımcıların yaş dağılımına bakıldığı zaman, \%11,0'nin 20 ve daha küçük, \%26,8'nin 21, \%21,5'nin 22, \%17,6'sının 23 ve \%23,1'nin ise 24 ve daha büyük yaşta oldukları bulunmuştur. Ingiltere'deki katılımcıların, \%43,4'ünün 20 ve daha küçük, \%21,7'sinin 21, \%17,0'sinin 22, \%7,7'sinin 23 ve \%10,2'sinin ise 24 ve daha büyük yaşta oldukları saptanmıştır.

Katılımcıların medya takip sıklıklarına bakıldığında ise; Tablo 1'den de görüldüğü gibi, Türkiye'deki katılımcıların \%43,3'ü yılda birkaç kez, \%37,0'si ayda birkaç kez, \%11,0'i haftada birkaç kez, \%1,3'ü her gün dergi okumaktadır. Katılımcıların \%7,4'ü ise dergi okumamaktadır. İngiltere'deki katılımcıların ise \%35,3'ü yılda birkaç kez, \%32,3'ü ayda birkaç kez, \%16,6'sı haftada birkaç kez, \%3,4'ü her gün dergi okurken, \%12,4'ünün dergi okumadığı saptanmıştır. Genel olarak bakıldığında, Türkiye'deki gençlerin dergi okuma sıklığının İngiltere'deki gençlerden daha yüksek olduğunu söylemek mümkündür.

Tablo 1. Katılımcıların dergi okuma sıklığı

\begin{tabular}{|l|c|c|c|c|c|c|c|c|c|c|c|c|}
\hline & \multicolumn{4}{|c|}{ Türkiye } & \multicolumn{5}{c|}{ İngiltere } \\
\hline & $\begin{array}{c}\text { Kadın } \\
(\mathrm{n}=202)\end{array}$ & \multicolumn{2}{c|}{$\begin{array}{c}\text { Erkek } \\
(\mathrm{n}=179)\end{array}$} & $\begin{array}{c}\text { Toplam } \\
(\mathrm{n}=381)\end{array}$ & $\begin{array}{c}\text { Kadın } \\
(\mathrm{n}=130)\end{array}$ & \multicolumn{2}{c|}{$\begin{array}{c}\text { Erkek } \\
(\mathrm{n}=105)\end{array}$} & \multicolumn{2}{|c|}{ Toplam (n=235) } \\
\cline { 2 - 15 } & $\mathrm{f}$ & $\%$ & $\mathrm{f}$ & $\%$ & $\mathrm{f}$ & $\%$ & $\mathrm{f}$ & $\%$ & $\mathrm{f}$ & $\%$ & $\mathrm{f}$ & $\%$ \\
\hline Her gün & 3 & 1,5 & 2 & 1,1 & 5 & 1,3 & 4 & 3,0 & 4 & 3,8 & 8 & 3,4 \\
\hline
\end{tabular}




\begin{tabular}{|l|r|r|r|r|r|r|r|r|r|r|r|r|}
\hline $\begin{array}{l}\text { Haftada } \\
\text { birkaç kez }\end{array}$ & 19 & 9,4 & 23 & 12,9 & 42 & 11,0 & 24 & 18,5 & 15 & 14,3 & 39 & 16,6 \\
\hline $\begin{array}{l}\text { Ayda birkac } \\
\text { kez }\end{array}$ & 74 & 36,6 & 67 & 37,4 & 141 & 37,0 & 52 & 40,0 & 24 & 22,9 & 76 & 32,3 \\
\hline $\begin{array}{l}\text { Yilda birkac } \\
\text { kez }\end{array}$ & 90 & 44,6 & 75 & 41,9 & 165 & 43,3 & 37 & 28,5 & 46 & 43,8 & 83 & 35,3 \\
\hline Okumayanlar & 16 & 7,9 & 12 & 6,7 & 28 & 7,4 & 13 & 10,0 & 16 & 15,2 & 29 & 12,4 \\
\hline Toplam & 202 & 100 & 179 & 100 & 381 & 100 & 130 & 100 & 105 & 100 & 235 & 100 \\
\hline
\end{tabular}

Katılımcıların okumayı tercih ettikleri dergi türlerine bakıldığında ise ilk beş tercih Türkiye'de sırası ile Kültür ve Sanat $(\% 36,5)$, Spor $(\% 28,4)$, Bilim ve Teknoloji $(\% 24,1)$, Sinema ve Televizyon $(\% 18,1)$ ve Magazin $(\% 15,5)$ dergileri iken, İngiltere'deki katılımcıların tercihleri, Moda (\%51,0), Magazin (\%31,8), Güzellik $(\% 30,5)$, Spor $(\% 28,4)$ ve Sağlık $(\% 15,3)$ dergileri olarak bulunmuştur. Bu bulgulardan hareketle, İngiltere'deki gençlerin moda, magazin ve güzellikle ilgili dergileri takip etme eğilimlerinin, Türkiye'deki gençlerden daha fazla olduğunu söylenebilir.

Gazete okuma sıklıklarına ilişkin analizler Tablo 2'de gösterilmektedir. Elde edilen bulgulara göre Türkiye'deki katılımcıların \%55,9'u her gün, \%28,4'ü haftada birkaç kez, \%6,0'sı yılda birkaç kez, \%5,6'sı ayda birkaç kez gazete okurken, \%4,1'i gazete okumamaktadır. İngiltere'de ise katılımcıların \%32,0'si haftada birkaç kez, \%20,0'si yılda birkaç kez, \%19,5'i ayda birkaç kez, \%15,4'ü her gün gazete okurken, \%13,1'inin gazete okumadığı belirlenmiştir. Türkiye'deki gençlerin gazete okuma sıklıklarının, İngiltere'deki gençlerden daha yüksek olduğunu söylemek mümkündür.

Tablo 2. Katıımcıların gazete okuma sıklığı

\begin{tabular}{|l|r|r|r|r|r|r|r|c|c|c|c|c|}
\hline & \multicolumn{4}{|c|}{ Türkiye } & \multicolumn{5}{c|}{ Ingiltere } \\
\hline & \multicolumn{2}{|c|}{ Kadın } & \multicolumn{2}{|c|}{ Erkek } & \multicolumn{2}{|c|}{ Toplam } & \multicolumn{2}{c|}{ Kadın } & \multicolumn{2}{c|}{ Erkek } & \multicolumn{2}{c|}{ Toplam } \\
\cline { 2 - 16 } & $\mathrm{f}$ & $\%$ & $\mathrm{f}$ & $\%$ & $\mathrm{f}$ & $\%$ & $\mathrm{f}$ & $\%$ & $\mathrm{f}$ & $\%$ & $\mathrm{f}$ & $\%$ \\
\hline Her gün & 109 & 54,0 & 104 & 58,1 & 213 & 55,9 & 17 & 13,1 & 19 & 18,1 & 36 & 15,4 \\
\hline Haftada birkaç kez & 66 & 32,7 & 42 & 23,5 & 108 & 28,4 & 30 & 23,1 & 45 & 42,9 & 75 & 32,0 \\
\hline Ayda birkaç kez & 11 & 5,4 & 10 & 5,6 & 21 & 5,6 & 31 & 23,8 & 15 & 14,3 & 46 & 19,5 \\
\hline Yılda birkaç kez & 13 & 6,4 & 10 & 5,6 & 23 & 6,0 & 33 & 25,4 & 14 & 13,3 & 47 & 20,0 \\
\hline Okumayanlar & 3 & 1,5 & 13 & 7,2 & 16 & 4,1 & 19 & 14,6 & 12 & 11,4 & 31 & 13,1 \\
\hline Toplam & 202 & 100 & 179 & 100 & 381 & 100 & 130 & 100 & 105 & 100 & 235 & 100 \\
\hline
\end{tabular}

Katılımcıların gazetede okumayı tercih ettikleri bölümlere ilişkin bulgulara bakıldığında; Türkiye'de; kültür ve sanat $(\% 39,8)$, spor $(\% 36,5)$, sinema $(\% 23,3)$, bilim ve teknoloji $(\% 23,1)$ ve magazin $(\% 20,0)$ bölümlerinin; Ingiltere'de ise spor $(\% 38,5)$, gündem $(\% 37,8)$, magazin $(\% 33,5)$, moda $(\% 26,4)$ ve sağlık $(\% 21,7)$ bölümlerinin okunduğu görülmektedir. Bu bulgularda en öne çıkan noktalardan biri, hem Türkiye hem de İngiltere'deki katılımcıların en çok okumayı tercih ettikleri ilk beş bölümün içerisinde magazin bölümünün bulunması olmuştur. 
Televizyon izleme sürelerine ilişkin farklılıkların ortaya konulması amacıyla t-testi yapılmıştır (Tablo 3). Türkiye'deki üniversite öğrencilerinin ortalama televizyon izleme süreleri hafta içi, hafta sonu ve genel ortalama farklılıkları bakımından İngiltere'deki üniversite öğrencilerinden daha yüksek bulunmuştur $(p=, 000)$.

Tablo 3. Televizyon izleme süresi farklılıklarına ilişkin t-testi sonuçları

\begin{tabular}{|c|c|c|c|c|c|c|}
\hline Değișken & Ülke & $\mathrm{N}$ & $\bar{x}$ & SS & $t$ & $p$ \\
\hline \multirow{2}{*}{ Hafta içi } & Türkiye & 381 & 10,88 & 11,69 & \multirow{2}{*}{6,142} & \multirow{2}{*}{, $000^{*}$} \\
\hline & İngiltere & 235 & 6,30 & 6,80 & & \\
\hline \multirow{2}{*}{ Hafta sonu } & Türkiye & 381 & 10,82 & 9,08 & \multirow{2}{*}{9,752} & \multirow{2}{*}{,000* } \\
\hline & İngiltere & 235 & 5,40 & 4,59 & & \\
\hline \multirow{2}{*}{ Toplam } & Türkiye & 381 & 21,70 & 18,63 & \multirow{2}{*}{8,540} & \multirow{2}{*}{, $000^{*}$} \\
\hline & İngiltere & 235 & 11,70 & 10,30 & & \\
\hline
\end{tabular}

${ }^{*} \mathrm{p}=0.01$ düzeyinde anlamlıdır

İngiltere ve Türkiye'deki katılımcıların televizyonda izlemeyi tercih ettikleri program türlerinin dağılımına bakıldığında ise; Türkiye'de haber $(\% 69,8)$, yabancı film ve dizi $(\% 44,7)$, yerli film ve dizi $(\% 33,9)$, spor $(\% 19,5)$ ve müzik $(\% 18,8)$ programları en fazla izlenen ilk beş program türü olarak bulunmuştur. Buna karşın İngiltere'deki katılımcıların en fazla takip ettikleri ilk beş program türü; yabancı film ve diziler $(\% 74,4)$, yerli film ve dizi $(\% 57,5)$, haberler $(\% 33,6)$, spor $(\% 31,9)$ ve yarışma $(\% 33,2)$ programlarıdır.

Sosyal medya kullanım farklılıklarına bakıldığında (Tablo 4), yapılan t-testi sonuçları da her iki ülkedeki üniversite öğrencilerinin sosyal medya kullanım süreleri arasında anlamlı farklılık olduğunu göstermiştir $(p=, 000)$. Türkiye'deki öğrencilerin sosyal medya kullanım sıklığının İngiltere'deki öğrencilerden daha fazla olduğu saptanmıştır.

Tablo 4. Sosyal medya kullanım süresi farklılıklarına ilişkin t-testi sonuçları

\begin{tabular}{|c|c|c|c|c|c|c|}
\hline Değișken & Ülke & $\mathrm{N}$ & $\bar{x}$ & SS & $t$ & $p$ \\
\hline \multirow{2}{*}{ Hafta içi } & Türkiye & 381 & 17,44 & 13,82 & \multirow{2}{*}{5,82} & \multirow{2}{*}{, $000^{*}$} \\
\hline & İngiltere & 235 & 11,22 & 9,21 & & \\
\hline \multirow{2}{*}{ Hafta sonu } & Türkiye & 381 & 12,17 & 21,55 & \multirow{2}{*}{4,91} & \multirow{2}{*}{, $000^{*}$} \\
\hline & İngiltere & 235 & 12,35 & 12,45 & & \\
\hline \multirow{2}{*}{ Toplam } & Türkiye & 381 & 29,62 & 7,52 & \multirow{2}{*}{5,99} & \multirow{2}{*}{, $000^{*}$} \\
\hline & İngiltere & 235 & 19,68 & 19,97 & & \\
\hline
\end{tabular}

${ }^{*} \mathrm{p}=0.01$ düzeyinde anlamlıdır

Katılımcıların sosyal medyada ziyaret ettikleri ağ türleri ise; Türkiye'de sosyal ağ(\%78), video ağları $(\% 57,0)$, mikroblog $(\% 56,4)$, fotoğraf ağları $(\% 25,7)$ ve blog $(\% 19,4)$ 
sayfaları iken; İngiltere'de sosyal ağ (\%90), mikroblog (\%53,9), video ağları (\%37), fotoğraf ağları $(\% 35,7)$ ve blog $(\% 12,8)$ olarak bulunmuştur.

Türkiye ve İngiltere'de bedene ilişkin tutumlarda medyanın rolü puanlarının t-testi sonuçlarına bakıldığında ise (Tablo 5); Geleneksel medyadan kaynaklanan baskı hissedilmesi $(\mathrm{t}=6,52 \mathrm{p}=, 000)$, sosyal medyadan kaynaklanan baskı hissedilmesi $(t=6,51 \mathrm{p}=, 000)$, medyada yer alan ünlülere benzemeye çalışılması $(t=7,21 \mathrm{p}=, 000)$, medyadaki ünlülerle bedenin karşılaştırılması $(t=6,00 \quad p=, 000)$ ve ideal beden farkındalığı $(t=9,35 \quad p=, 000)$ faktörlerinde ülkelere göre anlamlı farklılık olduğu belirlenmiştir $(p=, 000)$. Değişkenlerin tümünde İngiltere'deki katılımcıların puanlarının Türkiye'deki katılımcıların puanlarından yüksek olduğu bulunmuştur.

Tablo 5. Türkiye ve İngiltere'de bedene ilişkin tutumlarda medyanın rolü puanlarının ülke değişkenine göre t-testi sonuçları

\begin{tabular}{|c|c|c|c|c|c|c|}
\hline Değișken & Ülke & $\mathrm{N}$ & $\bar{x}$ & SS & $t$ & $p$ \\
\hline \multirow{2}{*}{$\begin{array}{l}\text { Geleneksel Medyadan } \\
\text { Kaynaklanan Baskı } \\
\text { Hissedilmesi }\end{array}$} & Türkiye & 381 & 34,16 & 15,94 & \multirow{2}{*}{6,52} & \multirow{2}{*}{, $000^{*}$} \\
\hline & İngiltere & 235 & 42,23 & 13,08 & & \\
\hline \multirow{2}{*}{$\begin{array}{l}\text { Sosyal Medyadan } \\
\text { Kaynaklanan Baskı } \\
\text { Hissedilmesi }\end{array}$} & Türkiye & 381 & 12,56 & 6,24 & \multirow{2}{*}{6,51} & \multirow{2}{*}{, $000^{*}$} \\
\hline & İngiltere & 235 & 15,75 & 5,35 & & \\
\hline \multirow{2}{*}{$\begin{array}{l}\text { Medyada Yer Alan Ünlülere } \\
\text { Benzemeye Çalıșılması }\end{array}$} & Türkiye & 281 & 9,62 & 5,37 & \multirow{2}{*}{7,21} & \multirow{2}{*}{, $000^{*}$} \\
\hline & İngiltere & 235 & 12,71 & 4,76 & & \\
\hline \multirow{2}{*}{$\begin{array}{l}\text { Medyada Yer Alan Ünlülerle } \\
\text { Bedenin Karșılaștırılması }\end{array}$} & Türkiye & 381 & 9,43 & 4,87 & \multirow{2}{*}{6,00} & \multirow{2}{*}{, $000^{*}$} \\
\hline & İngiltere & 235 & 11,76 & 4,33 & & \\
\hline \multirow{2}{*}{ İdeal Beden Farkındalığı } & Türkiye & 381 & 22,23 & 6,38 & \multirow{2}{*}{9,35} & \multirow{2}{*}{, $000^{*}$} \\
\hline & İngiltere & 235 & 27,73 & 8,09 & & \\
\hline
\end{tabular}

${ }^{*} \mathrm{p}=0.01$ düzeyinde anlamlıdır

\section{Model Testleri}

Yapılan literatür çalışmasından hareketle araştırmada önerilen modelde, bilgi kaynağı olarak medya, medyadan kaynaklanan baskı hissedilmesi ve ideal beden farkındalığı bağımsız değişkenler, medyadaki ünlülerle bedenin karşılaştırılması ve ünlülere benzemeye çalışılması ise bağımlı değişkenler olarak belirlenmiştir (Şekil 1). 


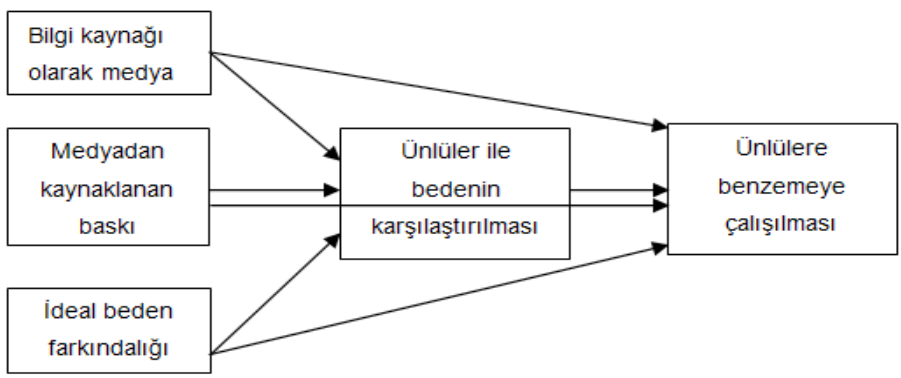

Şekil 1. Türkiye ve İngiltere için önerilen model

Yapılan, faktör analizi sonucunda, Türkiye ve İngiltere'de "bilgi kaynağı olarak medya" farklı madde faktör yük dağılımları gösterdiğinden, Türkiye için önerilen model; "Bilgi kaynağı olarak geleneksel medya, bilgi kaynağı olarak sosyal medya, geleneksel medyadan kaynaklanan baskı hissedilmesi, sosyal medyadan kaynaklanan baskı hissedilmesi ve ideal beden farkındalığı, ünlülerle bedenin karşılaştırılması ve ünlülere benzemeye çalışılmasını açıklar” biçiminde değiştirilmiştir (Şekil 2.).

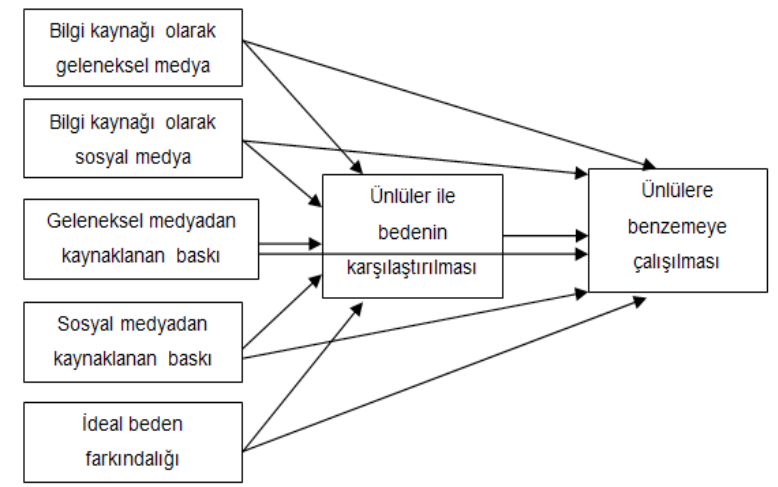

Şekil 2. Türkiye için test edilmesi önerilen model

Test edilen model önerisi Şekil 2'deki gibiyken, yapılan analizler sonrasında Şekil 3'deki model kabul edilmiştir.

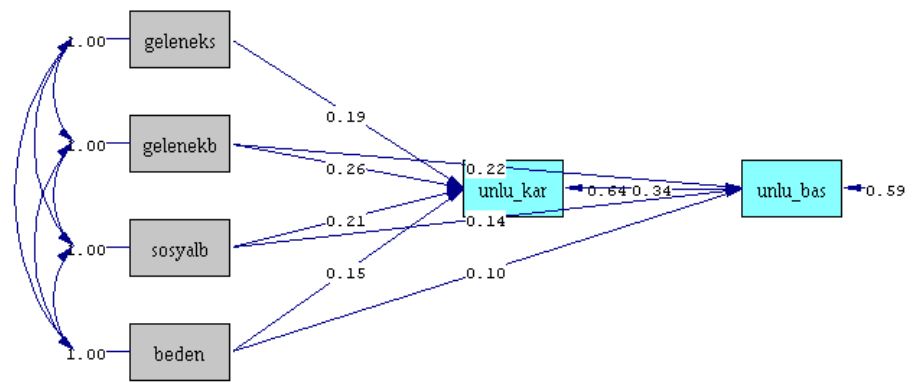

Şekil 3. Türkiye için önerilen değişimlerden sonra ortaya çıkan model 
Tablo 6. Türkiye için önerilen modele ilişkin uyum indeksleri

\begin{tabular}{|l|l|l|l|l|l|l|l|l|l|l|l|}
\hline Model & $\mathrm{c}^{2}$ & sd & (c 2 sd) & RMSEA & IFI & CFI & NFI & NNFI & GFI & CN & P \\
\hline Șekil 3 & 9,06 & 2 & 4,53 &, 071 &, 96 &, 96 &, 95 &, 90 &, 99 & 308,37 &, 004 \\
\hline
\end{tabular}

Modelin uyum indeksleri içinde yer alan ki-kare $\left(c^{2}\right)$ indeksi incelendiğinde (Tablo 6.) değerin 9,06 olduğu, ki-kare değeri ile serbestlik derecesine bakıldığında (c²/sd) oranın 5 'ten düşük olduğu görülmektedir. Bu da ilk uyum istatistik sonucunun uygun olduğunu göstermektedir. Ortalama karekök hata değeri (RMSEA) 0,071; karşılaştırmalı uyum indeksi (CFI) 0,96; normlandırılmış uyum indeksi ise (NFI) 0,95; uyum iyiliği indeksi (GFI) 0,99 çıkarak modelin uyum indekslerinin kabul edilebilir düzeyde olduğunu göstermektedir. Bu değerlerden yola çıkarak, beklenen ve gözlenen kovaryans matrisleri arasında uyumun sağlandığı, bu nedenle bu modelin doğrulandığı sonucuna ulaşılmıştır.

Kabul edilen model, "bilgi kaynağı olarak geleneksel medya, geleneksel ve sosyal medyadan kaynaklanan baskı hissedilmesi ve ideal beden farkındalığı, medyadaki ünlülerle bedenini karşılaştırma değişkenini açıklar. Medyadaki ünlülere benzemeye çalışılması değişkenini ise, sosyal medya ve geleneksel medyadan kaynaklanan baskı hissedilmesi, ideal beden farkındalığı ve medyadaki ünlülerle bedenini karşılaştırma değişkenlerini açıklar" olmuştur (Şekil 3.). Değişkenler arasındaki ilişkiler pozitiftir. Birbirini en fazla açıklayan/etkileyen değişkenler ünlülere benzemeye çalışmak ve medyadaki ünlülerle bedenini karşılaştırma değişkenleridir.

Yapılan faktör analizi sonrasında ortaya çıkan madde faktör yük dağılımlarından yola çıkılarak, İngiltere için önerilen model; "Bilgi kaynağı olarak gazete haricindeki medya, bilgi kaynağı olarak gazete, geleneksel ve sosyal medyadan kaynaklanan baskı hissedilmesi ve ideal beden farkındalığı, medyadaki ünlülerle bedenin karşıllaştırılması ve medyadaki ünlülere benzemeye çalışılması değişkenlerini açıklar” (Şekil 4.) olarak güncellenmiştir. Yapılan analizler sonrasında Şekil 5'deki model kabul edilmiştir.

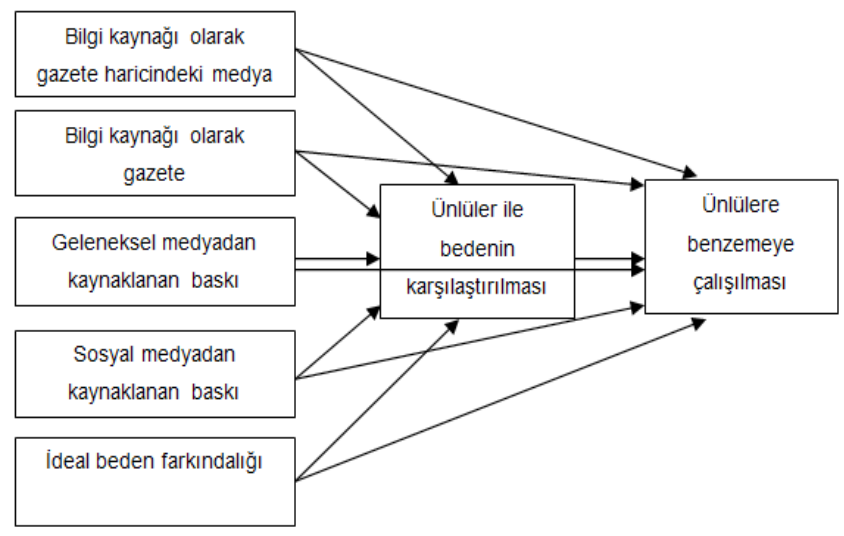

Şekil 4. İngiltere için test edilmesi önerilen model 


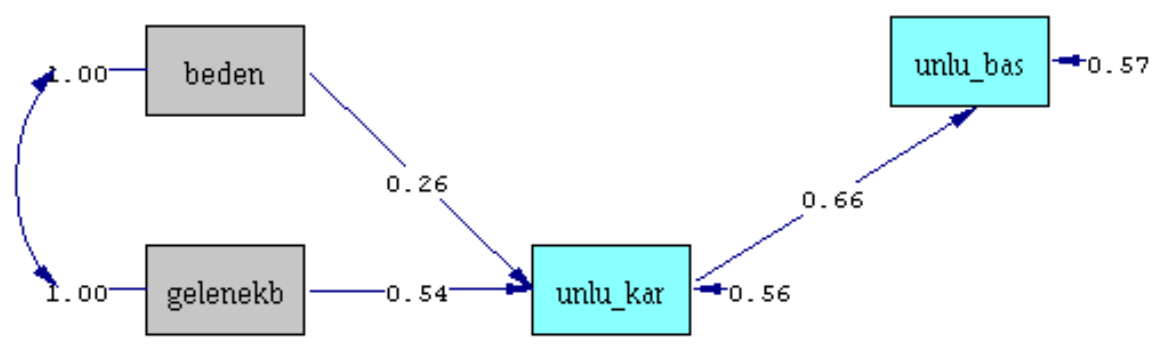

Şekil 5. İngiltere için önerilen değişimlerden sonra ortaya çıkan model

Tablo 7. İngiltere için önerilen modele ilişkin uyum indeksleri

\begin{tabular}{|l|l|l|l|l|l|l|l|l|l|l|l|}
\hline Model & $\mathrm{c}^{2}$ & sd & $\left(c^{2} / \mathrm{sd}\right)$ & RMSEA & IFI & CFI & NFI & NNFI & GFI & CN & $p$ \\
\hline Șekil 5 & 9,06 & 2 & 4,53 &, 071 &, 96 &, 96 &, 95 &, 90 &, 97 & 130,52 & 0,000 \\
\hline
\end{tabular}

Tablo 7.'deki uyum indeksi incelendiğinde, ki-kare $\left(c^{2}\right)$ indeksi değerinin 9,06 olduğu, ki-kare serbestlik derecesine bakıldığında ( $\left.c^{2} / s d\right)$ oranın 5 'ten düşük olduğu görülmektedir $(4,53)$. Bu da uyum istatistik sonucunun uygun olduğunu göstermektedir. Ortalama karekök hata değeri (RMSEA) ,071; karşılaştırmalı uyum indeksi (CFI) ,96; normlandırılmış uyum indeksi ise (NFI) ,95; uyum iyiliği indeksi (GFI) ,97 çıkarak modelin uyum indekslerinin kabul edilebilir düzeyde olduğunu göstermiştir. Bu değerlerden yola çıkarak beklenen ve gözlenen kovaryans matrisleri arasında uyumun sağlandığı görülmüş olup, model doğrulanmıştır.

İngiltere için kabul edilen model, "ideal beden farkındalığı ve geleneksel medyadan kaynaklanan baskının, kişinin bedenini ünlülerle karşılaştırmasını ve bu karşılaştırma sonrasında ünlülere benzemeye çalışı Imasını açıklar” biçiminde olmuştur (Şekil 5).

\section{Sonuç}

İki farklı ülkedeki üniversite öğrencilerinin medya kullanım sıklıkları ve tercihleri arasında anlamlı farklılıklar bulunmuştur. Test edilen modelde de bu farklıı̆̆ın yansımaları görülmektedir. Özellikle medya kullanım süre ve sıklıkları Türkiye'deki katılımcılarda daha yüksek iken, güzellik, moda ve magazin dergilerini takip etme oranları İngiltere'deki katılımcılarda daha yüksek bulunmuştur. Yapılan korelasyon analizinde medyadan kaynaklanan baskı hissedilmesi, medyada yer alan ünlülerle bedenin karşılaştırılması, medyada yer alan ünlülere benzemeye çalışılması ve ideal beden farkındalığı değişkenlerinde, İngiltere'deki gençlerin puanları Türkiye'deki gençlerden yüksek çıkmıştır. Bu sonuç medya kullanım sıklığının değil, medyada takip edilen içeriklerin daha önemli olduğunu göstermektedir. Örneğin İngiltere'de en fazla takip edilen dergi türü moda, güzellik ve magazin dergileri; en sık izlenen program türleri yabancı ve yerli film/diziler olarak görülmüştür. Daha önce Tiggemann ve Pickering (1996) tarafından yapılan araştırmada dizi ve film izlenmesinin bedenle ilgili düşünceleri etkilediği sonucu, bu çalışmada da doğrulanmıştır. Dergilerin beden üzerindeki etkisinin araştıııldığı diğer çalışmalarda (Levine ve Chapman, 2011; Morry ve Staska, 2001) güzellik ve moda dergisi okuma sıklığı ile bedene ilişkin 
memnuniyetsizlik arasındaki ilişki olduğu bulunmuştur, bu çalışmada elde edilen sonuçlar da bu ilişkiyi doğrulamaktadır.

Test edilen modelin çıktılarına göre Türkiye'de, beden imajına ilişkin bilgi kaynağı olarak geleneksel medya, medyadan kaynaklanan baskı hissedilmesi ve ideal beden farkındalığı bağımsız değişkenlerinin, medyada yer alan ünlülerle bedenin karşılaştırılması değişkenini açıkladığı görülmüştür. Medyadan kaynaklanan baskı hissedilmesi, ideal beden farkındalığı ve bedenin ünlülerle karşılaştırılması değişkenlerinin ise medyadaki ünlülere benzemeye çalışılması değişkenini açıkladığı saptanmıştır. İngiltere örneği için de, geleneksel medyadan kaynaklanan baskı hissedilmesi ve ideal beden farkındalığının, medyadaki ünlülerle bedenin karşılaştırılması değişkenini açıkladığı; medyadaki ünlülere benzemeye çalışılması değişkenini ise medyadaki ünlülerle bedenini karşılaştırma değişkeninin açıkladığı belirlenmiştir.

Her iki ülke için geliştirilen modelde geleneksel medyadan kaynaklanan baskı hissedilmesi, kişinin bedenini ünlülerle karşılaştırması ve ideal beden farkındalığı ile ünlülere benzemeye çalışılması değişkenleri arasında ilişki olduğu görülmüştür. Geleneksel medyadan kaynaklanan baskının daha fazla çıkması literatürdeki benzer çalışmaların sonuçlarını da desteklemektedir. Özellikle dergi, televizyon ve gazetenin bedene ilişkin ideallerin yayılmasında önemli olduğu, bununla birlikte medya kullanımına bağlı olarak kadın ve erkeklerde beden memnuniyetsizliğine neden olduğu bulguları (Field, vd., 2001; Graydon, 2008; Levine, vd., 1994), bu çalışma sonuçları ile de desteklenmiştir. Sosyal medya, önemli bir medya aracı olarak kabul edilse de, söz konusu beden imajı olduğunda geleneksel medyanın daha etkili olduğu görülmüştür.

Friedman (2002) yatay toplum kitabında şöhretlerin yatay toplumlarda nasıl var olduğunu ve o toplumda yaşayan halkları nasıl etkilediklerini anlatmış, toplumdaki kişilerin şöhretlere aşina olduklarını, sürekli medyada, özellikle de televizyonda yer almalarının bu aşinalığın ortaya çıkmasındaki en önemli nedenlerden biri olduğunu ifade etmiştir. Şöhretlerin dış görünüşleri, sesleri ve yaşam tarzları toplumdaki bireylere televizyon aracılığı ile yayılır, bu yayılma sonucunda çoğunlukla bu kişilere karşı hayranlık duygusu oluşur veya o şöhretler birer "idol" olarak görülmeye başlanır. Bir süre sonra kişiler kendilerini bu kişiler ile özdeşleştirirler. Bu araştırmanın sonucunda da ortaya çıkan medyadan kaynaklanan baskı hissedilmesi ve ideal beden farkındalığının, kişinin kendi bedenini ünlüler ile karşılaştırması ve bu karşılaştırma sonrasında o kişilere benzemeye çalışma isteğinin oluşmasına örnek olabilir.

Sonuç olarak, medyanın beden imajı üzerinde etkisinin olduğu söylenebilir. Medya takip sıklığından çok, medya kullanım tercihlerinin beden imajı üzerinde daha belirleyici olduğunu söylemek mümkündür. Güzellik ve moda ile ilişkili haber ve programları daha sık takip eden İngiltere'deki gençlerin daha fazla medyadan kaynaklanan baskı hissedilmesi, ideal beden farkındalıklarının daha yüksek olması, kendilerini medyadaki ünlülerle daha fazla karşılaştırmaları ve daha fazla benzemek istemeleri bu sonuçla açıklanabilir. 


\section{Kaynakça}

Beyazyüz, M. ve Göka, E. (2011).Psikoloji ve Tıp Açısından Beden, K. Canatan(Editör). Beden Sosyolojisi. İstanbul: Açıım Kitap, 371-395.

Botta, R. A. (1999). Television Images and Adolescent Girls' Body Image Disturbance. Journal of Communication, 49(2), 22-41.

Cafri, G., Yamamiya, Y., Brannick, M., \& Thompson, J. K. (2005). The Influence of Sociocultural Factors on Body Image: A Meta Analysis. Clinical Psychology: Science and Practice, 12(4), 421433.

Delvalle Institude Knowledge Base (2016) https://delvalle.bphc.org/mod/wiki/view.php?pageid=65. Erişim Tarihi 03.03.2017

Featherstone, M. (1993). The Body in Consumer Culture. The Body, Social Process and The Cultural Theory, Ed. Featherstone M., Hepworth M. ve Turner S. B. Sage Publication: Londra, s. 170-197.

Field, A. E., Camargo, C. A., Taylor, C. B., Berkey, C. S., Roberts, S. B., \& Colditz, G. A. (2001). Peer, Parent and Media Influences on the Development of Weight Concerns and Frequent Dieting Among Preadolescent and Adolescent Girls and Boys. Pediatrics, 107(1), 54-60.

Friedman, L. M. (2002). Yatay Toplum, İş Bankası Kültür Yayınları: İstanbul

Goswami, S., Sachdeva, S., \& Sachdeva, R. (2012). Body Image Satisfaction Among Female College Students. Industrial Psychiatry Journal, 21(2), 168-172.

Graydon, S. (2008). How the Media Keeps Us Hung-up on Body Image. Herizons, 22(1), 16-19.

Harrison, K., \& Cantor, J. (1997). The Relationship Between Media Consumption and Eating Disorders. Journal of Communication, 47(1), 40-67.

Hill, A.J. ve Franklin, J.A. (1998). Mothers, Daughters and Dieting: Investigating the Transmission of Weight Control. British Journal of Clinical Psychology, 37 (1), ss. 3-13.

Hollenbeck, C. R., \& Kaikati, A. M. (2012). Consumers' Use of Brands to Reflect Their Actual and Ideal Selves on Facebook. International Journal of Research in Marketing, 29(4), 395-405.

Irving, L. M. (1990). Mirror Images: Effects of The Standard of Beauty on the Self-and BodyEsteem of Women Exhibiting Varying Levels of Bulimic Symptoms. Journal of Social and Clinical Psychology, 9(2), 230-242.

Jones, D. C. (2011). Interpersonal and Familial Influences on the Development of Body Image. Eds. T. F. Cash \& L. Smolak, Body image: A Handbook of Science, Practice, and Prevention $\left(2^{\text {nd }}\right.$ ed., pp. 110-118). New York: Guilford Press.

Lee, H. R., Lee, H. E., Choi, J., Kim, J. H., \& Han, H. L. (2014). Social Media Use, Body Image and Psychological Well-Being: A Cross-Cultural Comparison of Korea and the United States. Journal of Health Communication, 19(12), 1343-1358. 
Levine, M. P., Smolak, L., \& Hayden, H. (1994). The Relation of Socio-cultural Factors to Eating Attitudes and Behaviors Among Middle School Girls. The Journal of Early Adolescence, 14(4), 471-490.

Levine, M. P. ve Chapman, K. (2011). Media Influences on Body Image, (Editör Cash, T. F., \& Smolak, L.) Body Image: A Handbook of Science, Practice and Prevention. Guilford Press.

Mondini, S., Favaro, A., \& Santonastaso, P. (1996). Eating Disorders and the Ideal of Feminine Beauty in Italian Newspapers and Magazines. European Eating Disorders Review, 4(2), 112-120.

Morry, M. M., \& Staska, S. L. (2001). Magazine Exposure: Internalization, Self-Objectification, Eating Attitudes and Body Satisfaction in Male and Female University Students. Canadian Journal of Behavioural Science/Revue Canadienne Des Sciences Du Comportement, 33(4), 269.

Myers, P. N., \& Biocca, F. A. (1992). The Elastic Body Image: The Effect of Television Advertising and Programming on Body Image Distortions in Young Women. Journal of Communication, 42(3), 108-133.

Oğuz, G.Y. (2005). Bir Güzellik Miti Olarak İncelik ve Kadınlarla İlgili Beden İmgesinin Televizyonda Sunumu. Selçuk Illetişim Dergisi, 4(1), 31-37.

Özbolat, A. (2011). Postmodern Dönemde Bedenin Tüketim Temelinde Yeniden İnşası. Elektronik Sosyal Bilimler Dergisi, 10(38), ss. 317-334.

Ricciardelli, L. A., McCabe, M. P., \& Banfield, S. (2000). Body Image and Body Change Methods in Adolescent Boys: Role of Parents, Friends and The Media. Journal of Psychosomatic Research, 49(3), 189-197.

Richins, Marsha. L. (1991). Social Comparison and Idealized Images of Advertising. Journal of Consumer Research, 18, 71-83.

Schilder, Paul (1950). The Image and the Appearence of the Human Body. International Press: NY

Selfhout, Maarten H.W., Branje, Susan J.T., Delsing, M., Bogt, Tom F.M. ve Meeus, Wim, H.J. (2009). Different Types of Internet Use, Depression and Social Anxiety: The Role of Perceived Frinedship Quality. Journal of Adolescence, 32, ss. 819-833.

Shilling, C. (1993). The Body and Social Theory. London: Sage Publications

Silverstein, B., Perdue, L., Peterson, B. ve Kelly, E. (1986). The Role of the Mass Media in Promoting a Thin Standard of Bodily Attractiveness for Women. Sex Roles, 14(9), 519-532.

Thompson, J. K., Van Den Berg, P., Roehrig, M., Guarda, A. S., \& Heinberg, L. J. (2004). The Socio-cultural Attitudes Towards Appearance Scale 3 (SATAQ 3): Development and Validation. International Journal Of Eating Disorders, 35(3), 293-304.

Tiggemann, M., \& Pickering, A. S. (1996). Role of Television in Adolescent Women's Body Dissatisfaction and Drive for Thinness. International Journal of Eating Disorders, 20(2), 199-203. 
Tiggemann, M., \& Mcgill, B. (2004). The Role of Social Comparison in the Effect of Magazine Advertisements on Women's Mood and Body Dissatisfaction. Journal of Social and Clinical Psychology, 23(1), 23-44.

Tiggemann, M. (2006). The Role of Media Exposure in Adolescent Girls' Body Dissatisfaction and Drive for Thinness: Prospective Results. Journal of Social and Clinical Psychology, 25(5), 523-541.

Tiggemann, M. (2011). Sociocultural Perspectives on Human Appearance and Body Image. Body Image: A Handbook of Science, Practice and Prevention, 12-19.

Warren, C. S., \& Rios, R. M. (2013). The relationships among acculturation, acculturative stress, endorsement of Western media, social comparison, and body image in Hispanic male college students. Psychology of Men \& Masculinity, 14(2), 192. 